Journal of Development and Communication Studies

Vol. 4. No. 1, January-June, 2015. ISSN (Online \& Print): 2305-7432.

http:/ / wnw.devcomsjournalmw.org.

(C) Journal of Development and Communication Studies, 2015.

\title{
What is the Difference between Cross-National Comparisons and Semi- Comparative Work? Example of Swedish-Ugandan Climate Change Communication Research
}

\section{Peter Berglez (PhD)}

\author{
Department of Media and Communication, Örebro University, Sweden, Email: \\ Peter.Berglez@oru.se \\ $\&$
}

Goretti Linda Nassanga $(\mathrm{PhD})$

Journalism and Communication Department, Makerere University, Uganda. Email: nassanga@,chuss.mak.ac.ug

\begin{abstract}
This methodological article presents the research approach of semi-comparisons and describes how it could be applied in the field of media and communication studies. The point of departure is that cross-national collaborations do not necessarily always have to result in full-fledged comparative studies, but can "go halfway", i.e. stay at the semi-comparative level. This is exemplified in terms of an ongoing long-term collaboration between Swedish and Ugandan researchers, focusing on sustainable communication involving the role of media as a provider of relevant information in the case of the climate change issue. The semi-comparative approach - here characterized by: 1) cross-national research connectivity, 2) activities in which one "puts one's own nation in a wider context" and 3) spontaneous, cross-national research influences - enables the generation of knowledge about the universalism and particularism within the dimensions of mediated climate communication, which would not have been possible with a regular cross-national comparative study.
\end{abstract}

Keywords: climate change, media, cross-national comparative research, semi-comparative approach, sustainable communication, universalism, particularism.

Cite this article as: Berglez, P. \& Nassanga, G.L. 2015. What is the Difference between Cross-National Comparisons and Semi-Comparative Work? Example of Swedish-Ugandan Climate Change Communication Research Journal of Development and Communication Studies, 4(1): 33-48. DOI: http://dx.doi.org/10.4314/jdcs.v4i1.3 


\section{Introduction}

In recent decades, cross-national comparative research, combined with quantitative or qualitative methods, has become widespread in media and communications studies (Downey \& Stanyer 2010; Livingstone 2003; Kittler 2014). In a globalizing world, international forms of knowledge become ever more necessary. However, in our experience, international research collaborations should not necessarily be assumed to involve cross-national comparative research studies. Such studies represent comparative research characterized by methodological standardization in which two or more countries are compared under one and the same scientific umbrella with a common theory, hypothesis, design, variables, etc., as for example in traditional international comparisons of media policies and systems (Curran et al. 2009) or media attention to climate change (Schmidt et al. 2013). In our view, comparative cross-national research activities which, for different reasons, do not develop into full-fledged cross-national comparisons, still generate relevant cross-national knowledge. This is not to say that regular crossnational comparative studies are not important or that they do not generate solutions or new knowledge. Instead, the idea is to widen the view on how cross-national knowledge could be conducted in a social scientific context.

Thus, the purpose of this article is to present the approach of semi-comparative work, which will be done based on our own Swedish-Ugandan research collaboration on climate change communication. Society's handling of one of humanity's biggest challenges, climate change, presupposes a sustainable development including well-working communication, i.e. sustainable communication (Boyce \& Lewis 2009). In this respect, climate change raises issues of how to: disseminate scientific calculations and uncertainties; establish a well-working dialogue between different actors and stakeholders; transform abstract climate science into information that is comprehensible to a wider audience; make different actors engage in the climate debate; and market and sell green solutions and products.

As most information on science and climate change comes from the media (Boykoff \& Roberts 2007; Carvalho 2008), media coverage is a big factor in the public understanding and response to climate change. However, due to different economic, social, political, ecological and/or cultural conditions around the world, the media communicative challenges look different in some respects in different countries. Thus, not least, what is required is ever more globalized understandings (Berglez 2008, 2013; Shanahan 2009) focusing on similarities and differences between the developed and developing countries. However, in establishing this kind of cross-national knowledge there is no "one-size-fits-all approach"; instead several pathways are available, and this is where semi-comparative work comes into the picture. In this article, we will seek to answer the following questions:

1) Why and in what ways are semi-comparisons implemented in our research collaboration concerning climate change and the role of media?

2) In what ways does the semi-comparative approach generate deepened scientific knowledge about our object of study, namely the role of media as a provider of sustainable communication, that is, as a provider of information relevant to mitigating and/or adapting to climate change? ${ }^{1}$

3) What is the relationship between cross-national comparative research and semicomparisons?

\footnotetext{
${ }^{1}$ By media here we mean traditional mass media such as newspapers.
} 
To begin with, the Swedish-Ugandan research project, which generated the semi-comparative approach in the first place, will be presented. This will be followed by an explanation of the theoretical concept of sustainable communication, and the challenges of universalism and particularism. Then, we will describe the intellectual process which finally resulted in semicomparative work. This will be followed by a presentation of our semi-comparative research collaboration, arranged according to the following themes: 1) cross-national research connectivity; 2) "putting-one's-own-nation-in-a-wider-context" activities, and 3) spontaneous cross-national research influence; as well as how they together help both the Swedish and Ugandan teams to better understand universal and particular dimensions of media's climate reporting.

\section{Background: SIDA Makerere-Örebro collaborative project}

As part of a SIDA (Swedish Development Agency) support program for capacity building to Makerere University in Uganda, several universities in Sweden have undertaken collaborations with various departments at Makerere University. Twelve units at Makerere University, including the Faculty of Arts, are receiving funding under the SIDA program. The Journalism and Communication Department (JCD) has been one of the beneficiaries, working in collaboration with the Department of Media and Communication at Örebro University. The departments at both Makerere and Örebro University have a common research area, focusing on climate change and the media. In line with the overall objective of the SIDA programme, JCD is conducting a research project with a principal researcher from Makerere who works in consultation with a co-researcher from Örebro University (together with their respective research colleagues and/or assistants in the two countries).

The research project, entitled "Exploring Communication Strategies for Enhancing Mitigation and Adaptation to Climate Change in the Lake Victoria Basin in Uganda" (20102015), targets for the most part rural subsistence farmers, who often lack access to resources, including information, due to their low income and educational level. Apart from exploring the farmers' access to various information sources and communication channels as well as assessing their climate information needs, the research project examines the other side, or the source of information, by evaluating the Ugandan media coverage of the climate issue. Thanks to the funding from SIDA, it has so far been possible for the researchers to meet at least twice a year to share their findings, either in Sweden or in Uganda.

In addition, media scholars in Örebro have been conducting a climate communication research project entitled "From Risk to Threat: Social Representations of Climate Change in the Media and among Citizens", originally funded by the Swedish Research Council, Formas (2008-2012). The project focused on the cultural, political and ideological effects of climate reporting in Sweden, and how the reporting could be improved in order to meet mitigation and adaptation oriented challenges.

\section{Western-Eastern development perspectives and the "middle way" in climate change discourse}

From the very beginning (2010), the common research interest in this Swedish-Ugandan collaboration - sustainable communication, understood as the important role of media in addressing climate change - has been premised on the "middle way" sustainability framework proposed by Servaes et al. (2012) and others (see also Tufte \& Metapulos 2009).

The initial, predominantly economic view of sustainable development, which has been termed the "Western" perspective (Servaes et al. 2012), was ably articulated by the Brundtland 
Commission (1987), set up by the UN in the 1980s to reconcile environmentalists and developmentalists (Vaillancourt 1995: 221). In its report, sustainable development is defined as "... development that meets the needs of the present without compromising the ability of future generations to meet their own needs" (Brundtland Report 1987: 41), and it was argued that economic and social sustainability also presuppose ecological sustainability.

However, while the developed countries realized economic growth, the Western perspective did not yield the expected results for the developing countries, prompting a revisiting of the Western approach. An important facet that came to be recognized was the element of equity, as formulated in the phrase "sustainable equitable development". Equity is viewed in terms of inter- and intra-generational equity, as including the entire globe or the developed North and developing South, and at the regional level as well as within countries. Another dimension of sustainable equitable development that has been added is that of instituting "...political systems that secure effective citizen participation in decision making and greater democracy in international decision making" (Vaillancourt 1995: 225).

The modified perspective, termed the "Eastern perspective", is closely associated with Phra Dhammapidhok, a Buddhist monk and philosopher, among other people. From the Buddhist perspective, sustainability concerns ecology, economy and evolvability, the latter concept referring to the potential for human beings to develop themselves into less selfish persons (Servaes et al. 2012: 103). Recognizing that development is multi-dimensional and differs from society to society, no single approach (Western or Eastern) has been universally applied to achieve development.

Thus, a synthesis of the Western and Eastern development perspectives is proposed by Servaes et al. (2012), which they term the "middle way", where development is seen as a relative concept and no society or country can contend that it is developed in every respect. A similar position is offered by Castro (2004) who argues that understanding sustainable development cannot be done primarily in terms of either the mainstream economic analysis or the various poststructuralist cultural theorists and ecological Marxists, but requires combining insights from various critical approaches and perspectives. Sustainable development involves partly different things in different countries and there is thus no absolute universal model which could be applied in all kinds of societies. "In other words, each society and community must attempt to delineate its own strategy to sustainable development" (Servaes et al. 2012: 105; see also Leye 2009).

All this could then be transferred to the communicative dimension of sustainable development, i.e. sustainable communication and the particular role of media. For example: how should media treat the climate issue in various countries and parts of the world in order to promote sustainable development? Furthermore, is it possible, or even desirable to also formulate a universal way of understanding sustainable communication about the climate issue that could be implemented anywhere, or should we simply abandon such an idea and admit the power of national and cultural differences? Is it reasonable that developing countries such as Uganda, which are mainly victims of climate change rather than being its cause, import the "Westernized" kind of climate communication that stresses mitigation action?

The IPCC Assessment Report 5 (AR5) states that “...with greater certainty than in previous assessments the fact that emissions of greenhouse gases and other anthropogenic drivers have been the dominant cause of the observed warming since the mid-20 century" (IPCC 2014 Press release). The report expresses concern that "...many risks constitute particular challenges for the least developed countries and vulnerable communities, given their limited ability to cope" (ibid). The former Chair of the IPCC, Rajendra Pachauri noted that "...many of those most vulnerable to climate change have contributed and contribute little to 
greenhouse gas emissions" (ibid). That being the case, should not mitigation action primarily be the responsibility of countries that cause climate change (the developed world plus China), including their media? (Friedman and Climate Wire 2014). Should not Ugandan authorities, as well as their media, be allowed to primarily focus on adaptation? Or, should they perhaps also concentrate on mitigation? There is no simple answer to these questions.

Thus, the long road towards sustainability ought to be characterized by the development of more knowledge on the matter of sustainable communication (see Ungar 2000; Ladwig et al. 2012; Berglez \& Olausson 2014). This gave rise to the idea that we, the Swedish and Ugandan researchers, should achieve some kind of cross-national comparative research, which finally culminated in the semi-comparative approach.

\section{The thorny path towards a semi-comparative approach}

Livingstone (2003) has noted that “...undoubtedly, one should not underestimate how much can be learned from colleagues from different cultures or what can be achieved given the combined creative intelligence of a diverse but focused group sharing their insights and energies" (2003: . 481). However, Kohn (1987) cautions that “. . . cross-national research comes at a price. It is costly in time and money, it is difficult to do, and it often seems to raise more interpretive problems than it solves" (Kohn 1987: 713). In order to find a suitable way of doing cross-national comparative research, we made use of Kohn's (1987) typology of potential approaches. To begin with, both research teams (in Sweden and Uganda) tended to adhere to the idea of the nation as object of study. Here, according to Kohn, the idea is to focus on the particular characteristics of two or more nations, in our case, mediated climate communication in Sweden and Uganda respectively. But such an approach would only partly capture our intended object of study, as we were both interested in sustainable communication globally. Thus, the two research teams were also eager to understand media's role in the climate change issue more generally, with Sweden representing the Global North, and Uganda the Global South. This, in turn, led the teams to another and contrasting approach in Kohn's model, one focusing on the nation as context, in which one should concentrate on how the particular (Swe/Uga) demonstrates more general mechanisms (concerning media's climate reporting in the developed and developing world).

However, to some extent, there was also some interest in a third cross-national approach presented by Kohn, the nation as part of a transnational context. According to Kohn, studies using this approach compare how common cross-continental phenomena or structures (cf. Berglez 2013) affect the domestic level, i.e. the nation. Both Sweden and Uganda are part of a common global ecological system/problem - climate change - and the question thus concerns how this system/problem shapes the climate reporting in Sweden and Uganda, and elsewhere, and how one can focus on both universal/similar and particular/different (i.e. culturally unique) dimensions simultaneously. Furthermore Kohn (1987) suggests a fourth approach, the nation as a unit, in which one seeks to "...establish relationships among characteristics of nations qua nations..." (Kohn 1987: 715) by classifying the nations along dimensions such as gross national product or education, which seemed relevant for our case but which perhaps works better in a study of more nations (than just two).

This far-reaching uncertainty about which cross-national approach to choose generated discussions on what to mainly focus on: similarities or differences. According to Livingstone (2003), “...depending on the countries compared, findings will centre more on similarities or on differences" (Livingstone 2003: 486). Here, it is perhaps taken for granted that a Sweden-

Uganda comparison ought to pay attention to differences rather than similarities (why else 
make a comparison?). In our case, we did not want to end up with a study of "obvious" differences between an economically rich and a poor country, which might seem like kicking in an open door. Instead, we were primarily interested in less obvious differences and similarities. Therefore, at a certain point we interrupted the process of designing a cross-national study and instead decided to map "obvious" differences and similarities between Sweden and Uganda concerning climate change and the role of media as well as underlying conditions that could explain it on a basic level. We wished to get this out of the way in order to then move on to the more interesting and complex similarities and differences between Sweden and Uganda. Here, we used both primary and secondary data, including some of our own previous studies:

\section{Affected in different ways and to various extents}

When it comes to the underlying conditions that are assumed to shape the character of climate communication in general, including media's reporting, it is important to begin by noting that Sweden is less affected by climate change than many other countries in the world, including Uganda. In Sweden, climate change is rather "invisible" and is thus more of an abstract scientific phenomenon (Berglez \& Olausson 2014). Uganda, on the other hand, is heavily dependent on agriculture, and changes in the climate concretely affect the livelihoods of the people (see UNFCC 2007:8). The reduced and irregular rainfall has led to a reduction in crop yields and caused food insecurity. Not surprisingly, given Uganda's high rate of population growth (3.5\%) and its having the seventh highest fertility rate globally (6.2) (Population Reference Bureau 2013), there have been increasing land conflicts as farmers try to expand the cultivable land, and more disputes over utilization of the scarce water resources. Uganda is already suffering from landslides due to settlements being built on mountain slopes, as well as floods resulting from cultivation of wetlands. All these impacts have aggravated the poverty levels (Hepworth \& Goulden 2008; Kumssa \& Jones 2010; McGrath 2008; Mearns \& Norton 2010; Mwiturubani \& Van Wyk 2010).

Climate change has also had negative implications for the health of Ugandans. The declining crop yields are leading to undernourishment and malnutrition, leaving people with weak bodies with low resistance to diseases such as malaria, the incidence of which has increased due to changing land use and increasing temperatures (Namanya 2009; UNFCC 2007). These differences in how Uganda and Sweden are affected by climate change clearly indicate the two countries have different communication "needs".

\section{Climate change awareness and media attention}

Another obvious difference concerns level of awareness about various dimensions of climate change, which was found to be very strong in Sweden but not in Uganda. In Swedish society, many informational and intellectual resources (scientific, political, journalistic, etc.) are available for explaining, understanding and analysing climate change. For example, some years ago, according to the Swedish Environmental Protection Agency (Naturvårdsverket 2009), 95\% of Swedes were convinced that climate change was real. In contrast, in 2010 a Gallup survey in Uganda found that those who viewed climate change as a "somewhat serious" or "very serious" threat were in the minority (45\%) (Corner 2011:9).

Sweden has a quite strong and long-standing tradition of environmental journalism (Djerf-Pierre 1996), which to a great extent is linked to the public engagement in several environmental issues and crises during the last 50 years (such as the nuclear energy question in the 1980s). However, environmental news is less prioritized than other news topics (crime, 
sports, etc.), especially in times of economic recession (Djerf-Pierre 2012). Swedish environmental journalists working for mainstream media often find it difficult to cover climate issues in a way that accords with the commercial "media logic" and its demand for spectacular events and angles which are sellable (Berglez 2011), and this is also the case in Uganda (Okomo-Okello 2011). However, in the wake of the last decade's climate boom in the Swedish news (Berglez et al. 2009), the climate issue has become a household word, which is not the case in Uganda. In Uganda, as in other non-industrialized countries, although the coverage of climate change is increasing, the quantity and quality of reporting do not match the scale of the problem (BBC 2010, Corner 2011; Okomo-Okello 2011; Shanahan 2009; Schmidt et al. 2013

Thus, the aforementioned differences in public perception of the climate issue can be partly explained by the differences in media access and the type of media coverage. In Sweden, more or less everyone has access to radio and owns a TV set. According to Nordicom media statistics, $83 \%$ of the population watch TV every day (2013), and $61 \%$ have access to a newspaper subscription (Nordicom 2015). According to World Internet Usage Statistics (2014), $94.8 \%$ of the Swedish population have access to Internet. While Sweden has very high access to media, Uganda's is quite low, apart from radio. In Uganda, radio access is $70 \%$ and $15 \%$ have access to TV (Uganda Communications Commission 2014). There is an estimated combined newspaper circulation of about 100,000 copies for a population of 35 million, which translates to about one copy for every 350 people. Internet access is still very low, with only $18.2 \%$ of the population being users (World Internet Usage Statistics 2014). Most of these are in urban areas, where there is use of social media especially amongst young people. The limited media access, particularly in the rural areas, limits people's ability to get information on measures for mitigation and adaptation to climate change. Because many are dependent on subsistence farming, this directly affects their livelihood.

Finally, in contrast to Sweden, the use of a foreign language in climate communication in Uganda is a hurdle to citizens' engagement in the climate debate, with climate terminology often being poorly understood, as there are no standard translations in the local languages. Therefore, in Uganda, many understand climate change as meaning changes in the weather or seasons (BBC 2010:5) or environmental changes broadly, neglecting its causes, impacts and implications for global sustainable equitable development.

\section{Different research needs}

So, after this "pre-study"/literature review, our intention was to continue with a study of less obvious similarities and differences between Sweden and Uganda, in which Kohn's idea about the nation as part of a transnational context seemed to be the most relevant approach for us to use. However, this was not realized. The difficulties of defining a cross-national study and a common research design had to do with the fact that the two teams (Swe/Uga) were prioritizing partly different research questions. In the Swedish context, in the wake of the 200710 climate boom in Swedish media, it seemed urgent to focus on whether or not the climate issue would be able to survive as a prioritized topic in mainstream media, while the Ugandan researchers were interested instead in how the climate issue could become established as a priority in the media. In addition, the main things that seemed to be needed in Sweden were qualitative studies of the development of media reporting, while in Uganda, there was a need for more quantitative studies to reflect the media coverage and media reception of the climate issue, especially in rural parts of the country. These differences made a full-scale comparative study between the countries even more difficult to accomplish. 


\section{Semi-comparative collaboration on sustainable communication (climate change and the role of media)}

These different factors and circumstances instead paved the way for the semi-comparative approach, in which cross-national knowledge has been generated in the following ways:

\section{Cross-national research connectivity}

To begin with, we decided to run joint seminars either in Sweden or in Uganda, in which the Swedish/Ugandan researchers have been able to present ongoing research and receive feedback. The regularity of these events has in turn facilitated Swedish-Ugandan "everyday communication" mainly through e-mail conversations which can concern, for example, exchange of research ideas, theoretical reasoning, discussions about the handling of different empirical materials, planning of joint participation at conferences, or tips about new literature and research events. In this way, the kind of national outlook too often found in social research, in which one tends to understand society, or even the world, only in terms of one's own nation (cf. Beck 2006) has continually been interrupted by an "external voice" which has reminded us not only of the social and cultural differences elsewhere, but also of possible similarities. In other words, at regular intervals an external collaborator sheds (external) light on one's object of study, which hopefully prevents epistemological provincialism.

Naturally, international exposure contributes to enriching research output, due to constant reading of comparative international studies as well as attendance at international conferences. Thus, as academics, we constantly take part in sharing and benefiting from access to scientific results from different parts of the world. At least this is the case when a researcher belongs to, for example, a Swedish university with great resources at its disposal, unlike in Uganda, where there are obvious material, technological and economic barriers to accessing scientific publications and attending international conferences. However, this kind of regular cross-national exchange of scientific results is a somewhat "abstract" and "distant" experience for us, compared to our recurrent conversations about the similarities and differences between Swedish and Ugandan environmental journalism in a collegial and networked context.

Consequently, relying only on attending conferences and reading publications would not have provided us with the same kind of deepened knowledge concerning our research area. For example, given that most theoretical literature and research findings derive from Europe and the US, what has been extensively discussed and reflected upon is which theoretical concepts, variables, approaches, etc. are de facto relevant for, and applicable in a Ugandan, but also a Swedish context, because of course not all studies and theories that derive from, for example, the US, are necessarily applicable to the case of Sweden. (See also below, on "spontaneous cross-national research influence".) Thus, this kind of "communicative" research collaboration goes beyond not only the aforementioned regular international exchange of research, but also regular cross-national comparative studies, whose collaborations often become rather impersonal, being based on instant transportation of data across continents and "measurement out of context", and lacking closer human contact between the involved researchers (Livingstone 2003: 482).

All in all, these collaborative "micro-activities" have generated a common bank of knowledge from which both the Swedish and Ugandan research have benefitted. Epistemologically speaking, one could put it the following way: "Ordinary" cross-national studies, which use methodological standardization (the formulation of a common scientific approach), generate cross-national knowledge that is detailed (as it delivers certain results about what is 
different/similar). Semi-comparative activities, on the other hand, do not deliver particular study results. Instead, they generate detailed and thorough knowledge in another form, namely knowledge that derives from joint scientific activity and discussions, and from participants' experiences of cross-national similarities/differences. This paves the way for an important cross-national competence that could be transferred to ongoing as well as future research and scientific activities.

\section{"Putting-one's-own-nation-in-a-wider-context" activities}

Furthermore, the cross-national research communication has also resulted in active participation in each other's fieldwork. This has primarily taken the form of a Swedish presence in the Ugandan field work, while the reverse will be arranged in the nearby future. A Swedish researcher took part in the pre-testing of the research tools for data collection in the Lake Victoria Basin, in Mayuge, a rural district in eastern Uganda. The data collected focused on farmers' ability to adapt to the negative consequences that climate change (not least, droughts) has on farming and livelihoods, as well as their access to relevant scientific information and communication channels such as radio and newspapers. In addition to taking part in the collection of empirical data and in conversations between the farmers and the Ugandan researcher, the Swedish researcher also shared his Swedish research project on media's climate reporting with a group of farmers.

From a Swedish perspective, these kinds of activities have generated a broader and richer view of what climate change adaptation de facto is and how it is discussed, handled and communicated in another part of the world. In Sweden, where ways to reduce $\mathrm{CO}_{2}$-emissions and mitigate harmful consequences are prioritized in the media as well as in policy-making, adaptation is conceived as pertaining to hypothetical future scenarios, and involves complex calculations and risk analysis about such things as possible floods or an influx of climate refugees (see for example, Storbjörk 2007). Thus, at least to some extent, empirical observations in a country such as Uganda, with its ever more visible present-day effects of climate change, could be used to help predict future effects of climate change in a country such as Sweden.

Furthermore, the "cognitive" bonds between Sweden and Uganda have been strengthened. Here, one could refer to what Jameson (1991) defines as global "cognitive mapping", i.e. the increasing need for more concrete experiences of the interdependencies between the Global North and South (see also Berglez 2013: 22-6). According to Jameson, despite the general awareness and knowledge about globalization and the causal links between different parts of the world, it still happens too often in society, including in the social sciences, that global relationships are disregarded, giving rise to "cognitive reification". However, in the Swedish-Ugandan "contextual" work, the seemingly abstract causal interdependence is anchored in "real" experiences and observations (cf. Moscovici 2001: 42), giving the complex global relations of climate change, emanating from social scientific reasoning, concrete contours and content. This, in turn, can be expected to improve the ability of researchers to develop relevant cross-national ideas about what (mediated) sustainable communication is and/or should be, locally and globally.

Furthermore, from a critical realistic point of view (Bhaskar 2008), these cross-national activities give proof of "transnationalized" scientific retroduction (see Danermark et al. 2002, pp. 96-8) in terms of ongoing scientific conversations between researchers from two different parts of the world. More precisely, the research objects - media's climate communication in Sweden and Uganda respectively - are continually being recontextualized (and thus potentially 
re-described) due to the inclusion of new dimensions and insights (from Sweden or Uganda) that previously were not empirically present/accessible.

When it comes to the planned "putting-one's-own-nation-in-a-wider-context" activities in Sweden, the plan is to invite one or several Ugandan researchers to take part in Swedish ethnographic media research on how journalists handle matters of climate change adaptation, and/or on the development of one or several climate/green information campaigns addressed to certain groups of Swedish citizens.

\section{Spontaneous cross-national research influence}

As a natural consequence of the above processes, both parties have also directly influenced each other's research. This could be described as cross-national influence of the spontaneous kind, because the influences have arisen as unplanned side-effects of the ongoing semicomparative conversations.

For example, research results have shown that Swedish mainstream news media tend to "individualize" climate change and thus emphasize the role of the individual as a potential "solver" of the global warming problem (Berglez et al. 2009; Dahl 2014). ${ }^{2}$ In this context, media encourage people to take action at the micro-level in their everyday lives, by doing things that mitigate $\mathrm{CO}_{2}$-emissions, like recycling, choosing public transport instead of the car, or reducing their consumption of meat (see also Berglez \& Olausson 2014). Another type of news discourse which has been quite prominent in the Swedish media reporting is the nationalization of climate change, i.e. the exclusive emphasis on the frontrunner state, Sweden, which is supposedly green and progressive (Hysing 2014) and a role model for other countries when it comes to climate smart ideas and communication.

These Swedish findings in particular generated lively discussions in the international research group. To begin with, the "individualizing" and "nationalizing" perspectives were considered to be confined to Sweden and some other developed countries. But at the same time it was possible to observe elements in the Ugandan media that indicated this was perhaps not the case. Therefore, the "Ugandan" team decided that these seemingly Western/Northern conceptualizations of the climate issue ought to be tested in Ugandan media. Interestingly, the Ugandan media was found to apply individualization, with attributions of responsibility and calls for action targeting the individual or community in almost a third of the selected articles in the study, provided that one also included adaptation-oriented discourse. For instance, the content of articles such as "Stop Lake Victoria pollution" (mitigation), "Watch out for animal diseases this rainy season" (adaptation), and "Plant wind breaks and prevent famine" (adaptation) all focus on individual action rather than describing climate change action merely as a matter of formal politics. ${ }^{3}$ Furthermore, a nationalizing approach to climate action,

\footnotetext{
2 The Swedish (qualitative) studies on individualization and nationalization are based on empirical data from the largest tabloid newspaper, Aftonbladet (1-30 November 2006) and the televised public service news programme Rapport (7-19 October 2005). See Berglez et al. (2009): 215-16.

3 This is based on findings from the research study, "Exploring Communication Strategies for Enhancing Mitigation and Adaptation to Climate Change in the Lake Victoria Basin in Uganda". The methodology included content analysis of media coverage of climate change for five months (February, April, June, August and October 2011) in the two national dailies with the highest circulation: The New Vision (NV) and The Monitor (M). (N=671)
} 
emphasizing Uganda's important role/responsibility, was applied in $46 \%$ of the studied articles. ${ }^{4}$ In some instances, nationalization was projected by invoking the former hegemonic status of Uganda to call for climate action so that the country can regain its former glory (the "Pearl of Africa", as Spencer-Churchill, believed to be the first Western explorer to discover the country, described it). Such headlines included: "Someone must stop the encroachment on our fragile wetlands", or "Conservation agriculture can save Uganda's farming". Reminding the nation of its former glory can potentially serve to galvanize climate action by creating a positive vision of sustainable development for the country (Corner 2011).

Another example of spontaneous cross-national research influence involves global journalism, which concerns media's ability to combine local and global discourses in reporting on events, and which has been studied rather extensively by the Swedish researchers (Berglez 2008, 2013). This has also inspired the Ugandans to focus on how and to what extent Ugandan media tends to "glocalize" the climate issue, i.e. connect the local with the global. Finally, on the Swedish side, the Ugandan conditions concerning climate change adaptation and the role of communication/media (see above), have now generated ideas on how to do media studies on the adaptation matter "up North", albeit in a partly different manner and using research questions adapted to the Swedish/Northern situation.

\section{Conclusion: the relation between cross-national comparative research studies and semi- comparative work}

Table 1 below presents a brief summary of the three dimensions of semi-comparative work:

Table 1: The characteristics of semi-comparative work.

\begin{tabular}{|l|l|}
\hline Semi-comparative work & Characteristics \\
\hline Cross-national research connectivity & $\begin{array}{l}\text { Ongoing exchange of results, theories, } \\
\text { methodological considerations, etc. between } \\
\text { research group from different countries } \\
\text { which is formalized in seminars, workshops or } \\
\text { regular meetings. }\end{array}$ \\
\hline $\begin{array}{l}\text { 'Putting-one's-own-nation-in-a-wider-context" } \\
\text { activities }\end{array}$ & $\begin{array}{l}\text { Deepened exchange through participation in } \\
\text { others' research activities, such as collection of } \\
\text { empirical data, ethnographic observations, or } \\
\text { dissemination of results. }\end{array}$ \\
\hline Spontaneous cross-national research influence & $\begin{array}{l}\text { Unconstrained implementation of the other } \\
\text { group's ideas, theoretical concepts, analytical } \\
\text { perspectives, variables, etc. in one's own } \\
\text { (domestic) research design. }\end{array}$ \\
\hline
\end{tabular}

${ }^{4}$ For example by calling on Ugandans to take action, especially in a case where the government wanted to give away Mabira Forest Reserve, considered a "national treasure", to a foreign investor to grow sugarcane. These headlines included: "Mabira is more than just a piece of land" (M 16/08/11); "Mabira cleans air, holds and captures carbon" (NV 13/10/11) and "We must guard our treasures against profiteers jealously" (M 16/08/11). 140 articles $(20.9 \%)$ targeted both the individual and government. Mabira Forest Reserve is one of Uganda's largest natural forests, covering an area of $306 \mathrm{sq} \mathrm{km}$ and having 312 species of trees, 315 species of birds, 218 species of butterflies, 97 species of moths, and 23 species of small mammals, as well as being the site of Griffin Falls (http://www.gorilla-safari.com/uganda-eco-tourism.html). 
Source: Authors

Altogether, since the beginning of the Swedish-Ugandan collaboration (2010), this semicomparative work has generated many fruitful discussions about universalism and particularism in media's handling of the climate issue; and about what is/ought to be similar or different in Sweden and Uganda as well as in the rest of the world. At the end of the day, these manifold discussions have also resulted in ideas for how to build and carry out a full-fledged crossnational study. Thus, at the present stage, we (finally) know which analytical perspectives and/or variables might work in a joint Swedish-Ugandan cross-national research study and perhaps a broader North-South study including other countries. Consequently, this kind of semicomparative work could be viewed as useful preparation for moving on to a full-scale crossnational comparison. In our interpretation, cross-national comparative research studies are all too often done without deeper discussions and analyses of how to handle national similarities and differences beforehand. Hence we argue that semi-comparative activities might help in avoiding potentially unnecessary validity problems.

The above reasoning may, however, give the impression that the semi-comparative process mainly offers a qualitative solution of a hermeneutic kind, providing interesting reflections but no "sturdy" knowledge, and that "real" cross-national comparative insights can only be achieved through quantitative solutions; i.e. by means of some quantitative analysis with more nomothetic, i.e. objective, scientific ambitions (Lindlof 1995: 22-3). In our view, however, the semi-comparative process does not necessarily have to lead to a cross-national comparative study. The production of the hermeneutic circle, i.e. the ongoing scientific conversations and interpretations of the analysed matter (Gadamer 1989), does not have to generate the presentation of some "concrete results". The intellectual and practical process of semi-comparison has a great scientific value in itself, as it generates deepened cross-national knowledge, although of a "semi-organized" kind. Provided that semi-comparative work gives rise to a full-scale cross-national study, it could of course be either quantitative qualitative, or both. It all depends on what kinds of research questions are being formulated (Kvale 1989).

The best way of generating more cross-national knowledge, whether about sustainable communication or in some other area, is probably to combine cross-national comparative studies and semi-comparative work and/or to simply apply them in different contexts (due to various reasons and motifs). Thus, semi-comparative work, an approach that definitely could be improved in several respects, is not the final answer to all the shortcomings of "regular" crossnational comparative research. Nevertheless, it does have the potential to contribute to deeper understandings and explanations of society and the world, as in the case of sustainable communication and the role of media.

\section{References}

BBC 2010

Least Responsible, Most Affected, Least Informed: Public understanding of climate change in Africa. London: BBC World Service Trust.

Beck, U. 2006.

The Cosmopolitan Vision. Cambridge \& Malden, MA: Polity Press.

Berglez, P. 2008.

What is Global Journalism? Theoretical and empirical conceptualizations

Journalism Studies, 9(6): 845-858. 
Berglez, P. 2011.

Inside, Outside, and Beyond Media Logic: Journalistic creativity in climate reporting, Media, Culture \& Society, 33(3): 449-465.

Berglez, P. 2013.

Global Journalism. Theory and practice. New York: Peter Lang.

Berglez, P. \& Olausson, U. 2014.

The Post-Political Condition of Climate Change: An ideology approach, Capitalism, Nature, Socialism, 25(1): 54-71.

Berglez, P., Höijer, B. and Olausson, U. 2009

Individualization and Nationalization of the Climate Issue. Two ideological horizons in Swedish news media. In Boyce, T. \& Lewis, J. (eds.) Media and Climate Change, (pp. 211-223). New York: Peter Lang.

Bhaskar, R. 2008.

A Realist Theory of Science. London: Verso.

Boyce, T. and Lewis, J. (eds.) 2009.

Climate Change and the Media. New York: Peter Lang.

Boykoff, M. T. \& Roberts, J.T. 2007.

Media Coverage of Climate Change: Current trends, strengths, weaknesses.

Brundtland Report .1987.

Human development report office. New York: UNDP.

Our Common Future. http://www.un-documents.net/our-common-future.pdf

(Accessed 10 May 2015)

Carvalho, A. 2008.

Communicating Climate Change: Discourses, mediations and perceptions.

Braga: Centro de Estudos de Comunicação e Sociedade, Universidade do

Minho.

Castro, C. J. 2004.

Sustainable Development: Mainstream and critical perspectives, Organization \&

Environment, 17(2): 195-225.

Corner, A. 2011.

Hidden Heat Communicating Climate Change in Uganda: Challenges and

opportunities. Kampala: PANOS Eastern Africa.

Curran, J., Lyengar, S., Brink Lund, A. and Salovaara-Moring, I. 2009.

Media System, Public Knowledge and Democracy: A comparative study, European Journal of Communication, 24(1): 5-26.

Dahl, E. 2014.

If Handling Environmental Problems is Up to Me: Individuals negotiate their environmental problems. PhD dissertation. Linköping: Linköping Studies in Arts and Science No. 615.

Danermark, B., Ekström, M., Jakobsen, L. and Karlsson, J. Ch. 2002.

Explaining Society: Critical realism in the social sciences. London: Routledge.

Djerf-Pierre, M. 1996.

Gröna nyheter: miljöjournalistiken i televisionens nyhetssändningar: miljö, natur, Sverige 1961-1994 [Green news: Environmental Journalism in Television News: Environment, nature, Sweden 1961-1994]. PhD dissertation.

Gothenburg: University of Gothenburg.

Djerf-Pierre, M. 2012. 
The Crowding-Out Effect: Issue dynamics and attention to environmental issues in television news reporting over 30 years, Journalism Studies 13(4): 499_ 512.

Downey, J. and Stanyer, J. 2010.

Comparative Media Analysis: Why some fuzzy thinking might help. Applying fuzzy set qualitative analysis to the personalization of mediated political communication, European Journal of Communication 25(4): 331-347.

Friedman, L. and Climate Wire. 2014 (April 9).

What Can Scientists Say about Ethics and Economics of Combating Climate Change?, Scientific American. http://www.scientificamerican.com/article/whatcan-scientists-say-about-ethics-and-economics-of-combating-climate-change/ (Accessed 10 May 2015)

Gadamer, H-G. 1989.

Truth and Method. London: Sheed and Ward.

Hepworth, N. \& Goulden, M. 2008.

Climate Change in Uganda: Understanding the implications and appraising the

Hysing, E. 2014. response. Edinburgh: LTS International.

A Green Star Fading? A critical assessment of Swedish environmental policy, Environmental Policy and Governance, 24(4): 262-274.

IPCC. 2014 (November 2).

IPCC Press Release

https://www.ipcc.ch/pdf.ar5/prpc syr/11022014 syr copenhagen.pdf.

(Accessed 7 May 2015)

Jameson, F. 1991.

Postmodernism or, the Cultural Logic of Late Capitalism. Durham, NC: Duke University Press.

Kittler, J. 2014.

Michel Chevalier and the Saint-Simonian Legacy: Early roots of modern crossnational comparative communication research, International Communication Gazette 76(3): 296-315.

Kohn, M. L. 1987.

Cross-National Research as an Analytic Strategy, American Sociological Review, 52 (December): 713-731.

Kumssa, A. \& John, J. F. 2010.

Climate Change and Human Security in Africa, International Journal of Sustainable

Development \& World Ecology 17(6): 453 - 461.

Kvale, S. (Ed.) 1989.

Issues of Validity in Qualitative Research. Lund: Studentlitteratur.

Ladwig, P., Dalrymple, K.E., Brossard, D., Scheufele, D.A., and Corley, E.A. 2012.

Perceived Familiarity of Factual Knowledge? Comparing operationalizations of scientific understanding, Science and Public Policy, 39(6): 761-774.

Leye, V. 2009.

UNESCO's Communication Policies as Discourse: How change, human development and knowledge relate to communication, Media, Culture \& Society 31(6): 939-956.

Lindlof, T.R.1995. 
Qualitative Communication Research Methods. Thousand Oaks, London \& New Delhi: Sage Publications.

Livingstone, S. 2003.

On the Challenges of Cross-National Comparative Research, European Journal of Communication, 18(4): 477-500.

McGrath, J. 2008.

Turning up the Heat: Climate change and poverty in Uganda. Oxfam GB.

Mearns, R. \& Norton, A. (eds.). 2010.

The Social Dimensions of Climate Change: Equity and vulnerability in a warming world. Washington DC: The World Bank.

Moscovici, S. 2001.

Social Representations: Explorations in social psychology. New York: New York

University Press.

Mwiturubani, D. A. \& Van Wyk, J-A. 2010.

Climate Change and Natural ResourcesConflicts in Africa. Institute for Security Studies. http://www.issafrica.org/uploads/Mono170.pdf. . (Accessed 10 May 2015)

Namanya, D. B. 2009.

An Assessment of the Impact of Climate Change on the Health Sector in Uganda: A case of malaria and cholera epidemics and how to improve planning for effective preparedness and response. Kampala: Ministry of Health.

Naturvårdsverket. 2009.

Allmänheten och klimatförändringen 2009 [The Public and Climate

Change 2009] Rapport 6311. Stockholm: Naturvårdsverket.

Nordicom mediestatistik. 2015. http://www.nordicom.gu.se/mediefakta/mediestatistik (Accessed 10 May 2015)

Okomo-Okello, F. 2011.

Media Coverage of Climate Change in East Africa: Importance, challenges, opportunities and needs. Retrieved from http://ej.msu.edu/.../Okello Media Coverage.ppt. (Accessed 10 May 2015)

Population Reference Bureau. 2013.

World Population Data Sheet. Washington.

http://www.prb.org/Publications/Datasheets/2013/2013-world-populationdata-sheet.aspx (Accessed 4 June 2015)

Schmidt, A., Ivanova, T. \& Schäfer, M. 2013.

Media Attention for Climate Change around the World: A comparative analysis of newspaper coverage in 27 countries, Global Environmental Change, 23(5): 12331248.

Servaes, J., Polk, E., Shi, S., Reilly, D. and Yakupitijage, T. 2012.

Towards a Framework of Sustainability Indicators for 'Communication for Development and Social Change Projects', International Communication Gazette, 74(2): 99-123.

Shanahan, M. 2009.

Time to Adapt? Media Coverage of Climate Change in Non-industrialised

Countries. In Boyce, T. \& Lewis, J. (eds.) Climate Change and the Media (pp. 145157). New York: Peter Lang. 
Storbjörk, S. 2007.

Governing Climate Adaptation in the Local Arena: Challenges of risk management and planning in Sweden, Local Environment: The International Journal of Justice and Sustainability, 12(5): 457-469.

Tufte, T. \& Mefalopulos, P. 2009.

Participatory Communication: A practical guide. Washington, DC: World Bank Working Papers No. 170.

Uganda Communications Commission. 2014.

Access and Usage Survey http://www.ucc.co.ug./data/dnews/50/UCC-Acessand-Usage-Survey-2014.html. (Accessed 7 May 2015)

UNFCC. 2007.

Climate Change: Impacts, vulnerabilities and adaptation in developing countries. Bonn: UNFCCC. http://unfccc.int/resource/docs/publications/impacts.pdf . (Accessed 4 June 2015)

Ungar, S. 2000.

Knowledge, Ignorance and the Popular Culture: Climate change versus the ozone hole, Public Understanding of Science 9(3): 297-312.

Vaillancourt, J-G.1995.

Sustainable Development: A sociologist's view of the definition, origins and implications of the concept.In Mehta, M.D. and Ouellet, É. (eds) Environmental Sociology. Theory and Practice, pp. 219-230. North York: Captus Press.

World Internet Usage Statistics. 2014.

http://www.internetworldstats.com/stats.htm (Accessed 10 May 2015) 